\title{
The Craniospinal Venous System
}

\author{
J.M.S. Pearce \\ Emeritus Consultant Neurologist, Department of Neurology, Hull Royal Infirmary, Hull, UK
}

\section{Key Words}

Craniospinal veins $\cdot$ Venous plexus $\cdot$ Valveless venous

system $\cdot$ Metastatic spread

\begin{abstract}
The valveless craniospinal venous system consists of veins and plexuses that communicate freely and whose flow is bidirectional. It comprises (1) the intracranial-cortical veins, dural sinuses, cavernous sinuses and ophthalmic veins, and (2) the vertebral venous plexuses, which freely anastomose with the intracranial venous system. The vertebral venous plexuses anastamose with the sacral, pelvic and prostatic venous plexus. It is clinically important since it provides a route for the spread of tumours, infection or emboli. This route may go unrecognised.

Copyright $\odot 2006$ S. Karger AG, Base
\end{abstract}

The venous connection between the cranium, spine, and pelvic organs is a clinically important and often imperfectly understood section of anatomy. As Batson [1] pointed out, '[the] great functional complex of veins would escape recognition as a system until $1940 \ldots$ In the first four decades of the last century, our knowledge of the vertebral veins was developed and then almost forgotten'.

In 1829, Breschet [2] had detailed the anatomy of the vertebral venous plexus, confirming the work of Bock [3]. 120 years later, Batson's [3] groundbreaking studies em- ployed dissections, corrosion studies and injection [4-7] in human cadavers and living primates. Angiography proved an important additional technique utilised by Anderson [8] and others. Tobinick [9] has provided an excellent review.

\section{Clinical Relevance}

The craniospinal venous system (CSVS) is a pathway for the rostral metastatic spread of cancer from the prostate, bladder and uterus, and it is also important in ascending infections from pelvic organs, which can cause venous infarction of the cord. Cells can be carried via the CSVS in either a rostral or caudal direction. Metastasis to the spinal canal and cavernous sinus has been described from squamous cell carcinoma of the face; caudal spread from medulloblastomas to the spinal canal is also well known. Percutaneous vertebroplasty and kyphoplasty can result in cement in the epidural venous plexus that may lead to an ascending venous thrombosis; or acrylic may extend from the paraspinous veins into the vena cava and may result in a pulmonary embolus. Serious neurological (and cardiopulmonary) complications relate to the extrusion of bone cement into the vertebral venous system.

Oral contraceptives, congenital protein-S deficiency, protein- $\mathrm{C}$ deficiency and anticardiolipin antibodies are more recently recognized precipitating factors for venoocclusive disorders.

\section{KARGER \\ Fax +41613061234 E-Mail karger@karger.ch} www.karger.com (c) 2006 S. Karger AG, Basel

0014-3022/06/0562-0136\$23.50/0

Accessible online at:

www.karger.com/ene
J.M.S. Pearce

304 Beverley Road

Anlaby, East Yorkshire, HU10 7BG (UK) 
Fig. 1. Vertebral veins and plexuses. Based on Groen et al. [10] .

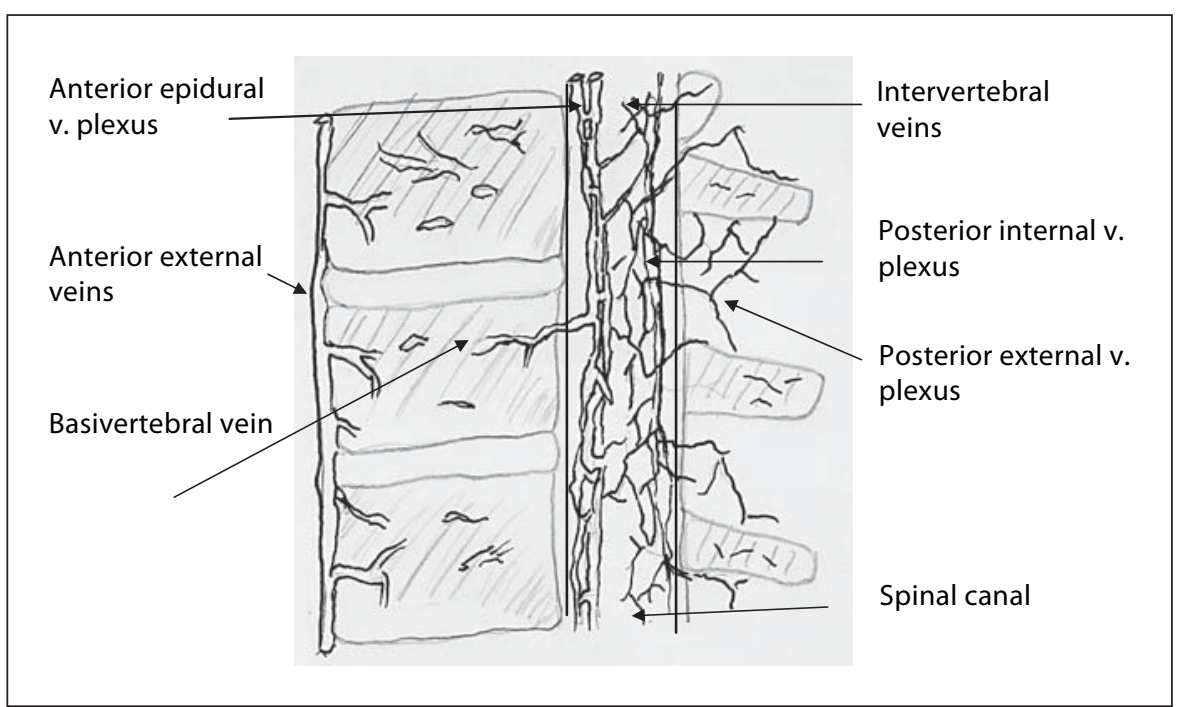

\section{Craniospinal Venous System}

The CSVS is involved in the maintenance of intracranial pressure, varying with respiration and postural changes. Modern investigation has shown the vertebral venous plexus as a rich anastomosis of valveless veins along the length of the spinal canal. For descriptive purposes, Groen et al. [10] separated the vertebral venous plexus into three intercommunicating divisions (fig. 1.): 1 the internal vertebral venous plexuses (anterior and posterior) lying within the spinal canal but external to the dura;

2 the external vertebral venous plexuses (anterior and posterior), which surround the vertebral column, and

3 the basivertebral veins, which run horizontally within the vertebrae [10].

Both the internal and external venous plexus extend along the entire length of the spine, from sacrum to cranium. Corrosion casting and injections of Araldite ${ }^{\circledR}$ show that the internal and external vertebral venous plexuses freely communicate, a finding confirmed by intraosseous spinal venography $[11,12]$. The posterior internal vertebral venous plexus has a striking segmental and individual variability.

Groen et al. [13] also showed the internal and external plexuses and that the basivertebral veins contained no valves and freely intercommunicated: '... due to the absence of valves, venous backflow from the internal vertebral venous plexus into the cerebral venous system occurs under physiologic conditions.'
However, the preferential direction of the flow during experimental flushing suggests the presence of functional valves, probably located in the thoracic posterior internal vertebral venous plexus [10]. The internal vertebral veins communicate with radicular, spinal and the external vertebral veins [10].

Batson [1] showed communication of the vertebral venous plexuses and the veins of the back and thoracoabdominal wall:

These vertebral veins have many and rich communications with the veins in the spinal canal, the veins around the spinal column, and those within the bones of the column. This system communicates with the segmental (intercostal) veins of the thoracoabdominal wall (including those of the breast) and with the azygous system of veins.

He also showed the connection of the venous systems of the spine and the dural venous sinuses:

... the vertebral veins are a valveless plexiform network with a longitudinal pattern. They parallel and communicate with the superior and inferior venae cavae. The plexus extends the entire length of the vertebral column and finds a cranial terminus in the dural sinuses.

There is also an anastomosis of the intracranial venous system and the veins of the scalp, skull and face, particularly important in the spread of cutaneous and soft tissue infection into the cavernous sinuses.

'Throughout the cranium the veins of the brain, the veins of the meninges (the venous sinuses), and the veins of the skull bones themselves (the diploic veins), and the veins of the various extracranial plexuses anastomose richly.' 


\section{Venous Flow to and from the Brain}

Herlihy [14] noted that the vertebral veins were the largest and by far the most important accessory pathway for venous return from the cranium. In healthy human volunteers in the supine position, the resting venous blood flow is about $766 \pm 226 \mathrm{ml} / \mathrm{min}$. Physiologically the flow is continually changing direction [3]. When the sagittal sinus is injected with contrast media in rhesus monkeys in the upright position, the vertebral venous plexus is the main route of venous outflow from the brain: a result confirmed by duplex sonography in man [15].

Caudally, the cranial veins and dural sinuses freely communicate with the sacral and pelvic veins and the prostatic venous plexus. Anderson [8] had injected $200 \mathrm{ml}$ of diodrast into the deep dorsal penile vein; skull films then showed:

... an accumulation of the opaque media in the superior sagittal sinus and in addition the confluens sinuum... and many of the superior cerebral veins are filled... the straight sinus is well filled... the great cerebral vein, the petrosal sinuses and a portion of the basilar plexus of veins are outlined.

\section{Conclusion}

The CSVS consists of veins, sinuses and venous plexuses that communicate freely. Because they are without valves their flow is bidirectional. The two main divisions of this system comprise (1) the intracranial veins and sinuses, and (2) the vertebral venous plexuses freely anastomose. The vertebral venous plexuses also anastamose with the sacral, pelvic and the prostatic venous plexus. Clinically, the CSVS provides a direct vascular route for the spread of tumours, infection or emboli among its different components, in either direction. The vertebral venous plexus is often referred to as Batson's plexus: a just eponym recalling his original investigations over 60 years ago.

\section{References}

1 Batson OV: The function of the vertebral veins and their role in the spread of metastases. Ann Surg 1940;112:138-149.

2 Breschet G: Recherches anatomiques physiologiques et pathologiques sur le système veineux. Paris, Rouen frères, 1829.

3 Bock A: Darstellung der Venen des menschlichen Körpers. Leipzig, Baumgärtner, 1823.

4 Batson OV: The vertebral vein system as a mechanism for the spread of metastases. Am J Roentgenol Radium Ther 1942;48:715718.

5 Batson OV: The role of the vertebral veins in metastatic processes. Ann Intern Med 1942; $16: 38-45$.
Batson OV: The Valsalva maneuver and the vertebral vein system. Angiology 1960;11: 443-447.

7 Batson OV: The vertebral system of veins as a means for cancer dissemination. Prog Clin Cancer 1967;3:1-18.

8 Anderson R: Diodrast studies of the vertebral and cranial venous systems to show their probable role in cerebral metastases. J Neurosurg 1951;8:411-422.

9 Tobinick E: The cerebrospinal venous system: anatomy, physiology, and clinical implications. Medscape Gen Med 2006;8:53.

10 Groen RJ, du Toit DF, Phillips FM, et al: Anatomical and pathological considerations in percutaneous vertebroplasty and kyphoplasty: a reappraisal of the vertebral venous system. Spine 2004;29:1465-1471.
11 Clemens HJ: Die Venensysteme der menschlichen Wirbelsäule; Morphologie und funktionelle Bedeutung. Berlin, De Gruyter, 1961.

12 Vogelsang H: Intraosseous spinal venography. Amsterdam, Excerpta Medica, 1970.

13 Groen RJ, Groenewegen HJ, van Alphen HA, et al: Morphology of the human internal vertebral venous plexus: a cadaver study after intravenous Araldite CY 221 injection. Anat Rec 1997;249:285-294.

14 Herlihy WF: Revision of the venous system: the role of the vertebral veins. Med J Aust 1947;1:661-672.

15 Epstein HM, Linde HW, Crampton AR, et al: The vertebral venous plexus as a major cerebral venous outflow tract. Anesthesiology 1970;32:332-337. 